\section{Evaluation of Captured Rainwater and Irrigation Runoff for Greenhouse Foliage and Bedding Plant Production}

Jianjun Chen ${ }^{1}$ and Richard C. Beeson, Jr. ${ }^{2}$

Mid-Florida Research and Education Center, IFAS, University of Florida, 2725 Binion Road, Apopka, FL 32703

\author{
Thomas H. Yeager ${ }^{3}$ \\ Department of Environmental Horticulture, IFAS, University of Florida, P.O. \\ Box 110670, Gainesville, FL 32611
}

Robert H. Stamps ${ }^{3}$

Mid-Florida Research and Education Center, IFAS, University of Florida, 2725 Binion Road, Apopka, FL 32703

\section{Liz A. Felter ${ }^{4}$ \\ Orange County Extension, University of Florida, 2350 E. Michigan Street, Orlando, FL 32806}

Additional index words. electrical conductivity, $\mathrm{pH}$, tropical foliage plants, water conservation, water quality

\begin{abstract}
Irrigation runoff water from a containerized landscape plant production bed was blended with rainwater from greenhouse roofs in a constructed collection basin. Water from both the collection basin and an on-site potable well were characterized and used to grow foliage and bedding plants with overhead and ebb-and-flow irrigation systems. Over a 2-year period, a total of 18 foliage and 8 bedding plant cultivars were produced with plant growth and quality quantified. Alkalinity, electrical conductivity, hardness, and concentrations of nutrients of water from both sources were well within desired levels for greenhouse crop production. Turbidity and $\mathrm{pH}$ were relatively high from algal growth in the collection basin. However, substrate $\mathrm{pH}$, irrigated by either water source, remained between 6 and 7 throughout the production periods. All plants at the time of finishing were of marketable sizes and salable quality independent of water source. No disease incidences or growth disorders related to water sources were observed. Results suggest that captured irrigation runoff blended with rainwater can be an alternative water source for greenhouse crop production.
\end{abstract}

Ornamental plant production is traditionally a heavy user of water; on an average, 1,883 to $6,276 \mathrm{~mm} \cdot \mathrm{ha}^{-1}$ of potable water per year may be applied as irrigation (Harrison, 1976). However, only $15 \%$ to $85 \%$ of surface-applied irrigation water enters containers, depending on irrigation methods, plant size, and container spacing (Beeson and Knox, 1991). If an overhead method is used, more

Received for publication 11 Jan. 2002. Accepted for publication 19 July 2002. Florida Agricultural Experiment Station journal series R-08613. Research was supported in part by the St. Johns River Water Management District, Fla. The views and conclusions contained in this document are those of the authors and should not be interpreted as necessarily representing the official polices, either expressed or implied, of the funding agent nor an endorsement of any registered product. We thank Russell D. Caldwell, Cynthia A. Robinson, and Yingfeng Huang for invaluable research assistance and Kelly Everitt for critical reading of this manuscript.

${ }^{1}$ Assistant Professor. To whom reprint requests should be addressed (Tel: 407-884-2034 Ex. 161;

E-mail: jjchen@mail.ifas.ufl.edu).

${ }^{2}$ Associate Professor.

${ }^{3}$ Professor.

${ }^{4}$ Extension Agent II. than $50 \%$ either leaches through containers or becomes runoff between containers (Neal and Henley, 1992). Runoff, leachate, and rainwater could be captured (collectively called captured water) and used as an irrigation source for nursery crop production.

Below average rainfalls since the early 1960 s, coupled with a concurrent population increase from 5 million to 13 million in Florida, resulted in the loss of aquifer recharge areas and led to heavy competition between the public and agriculture for potable water in the early 1990s (Burney et al., 1998). The Water Management Districts have encouraged the use of alternative water sources for crop production for nearly a decade (Neal and Henley, 1992). In addition to water conservation, capture of irrigation runoff can reduce the potential for nitrate and phosphorus contamination of ground and surface water. However, information on the quality of captured water and its effects on commercial containerized plant production is limited. Most studies have dealt with treated municipal water or reclaimed water (Berry et al., 1980; Fitzpatrick et al., 1986; Wu et al., 1995 ) or captured irrigation runoff for the production of containerized landscape ornamental plants (Camper et al., 1994; Quist et al., 1999;
Skimina, 1986; Yeager et al., 1989). There have been no previous reports on the use of the captured water for greenhouse containerized plant production.

The objective of this study was to compare growth and quality of container-grown foliage and bedding plants irrigated with captured water to those irrigated with well water in greenhouse production conditions.

\section{Materials and Methods}

Water collection basin and irrigation systems. A collection basin, $9.1 \mathrm{~m}$ long, 3.7 $\mathrm{m}$ wide, and $1.1 \mathrm{~m}$ deep, was excavated at the Univ. of Florida's Mid-Florida Research and Education Center in Apopka. Concrete was used to form the walls, and three layers of $0.15-\mathrm{mL}$ black polyethylene sheets were used to line the basin, which had a capacity of $26.5 \mathrm{~m}^{3}$ of water.

Soil excavated from the collection basin was used to elevate an existing containerized landscape plant production area to facilitate the recovery of irrigation water runoff and leachates into the collection basin. This production area was covered with two layers of $0.15-\mathrm{mL}$ black polyethylene over-laid with black polypropylene woven ground cloth (VJ Growers, Apopka, Fla.). The outdoor container area was $54.6 \mathrm{~m}^{2}$ and connected to the collection basin with PVC pipe. This production area was filled with plants of five landscape species: azalea (Rhododendron simsii Planch.), Mexican heather(Cuphea hyssopifolia HBK.), hibiscus (Hisbiscus rosa-sinensis L.), Japanese ligustrum (Ligustrumjaponicum Thumb.), and sweet viburnum (Viburnum odoratissimum Ker-Gawl.). Eighty rooted cuttings of each species were transplanted singly into $10.2-\mathrm{L}$ containers on 1 Apr. 1999 and placed in the area with a pot-to-pot spacing and 45 -cm walkway between species. The container substrate comprised $60 \%$ pine bark, $30 \%$ Florida sedge peat, and $10 \%$ coarse sand and amended with micronutrients $\left(0.89 \mathrm{~kg} \cdot \mathrm{m}^{-3}\right.$, Peter's Fritted Trace Minerals, Scotts Co., Marysville, Ohio) and dolomite $\left(2.3 \mathrm{~kg} \cdot \mathrm{m}^{-3}\right.$ dolomite limestone). Four controlled-release fertilizers [Meister's Hi-Temp Nursery Fertilizer 16-6-10 with micronutrients $(16.0 \mathrm{~N}-2.6 \mathrm{P}-8.3 \mathrm{~K}, 6$ month), Helena Chemical Co., Memphis, Tenn., Polyon's 16-5-10 with micronutrients (16.0N-2.2P-8.3K, 5-6 months), Pursel Technologies, Sylacauga, Ala., Polyon's 17-5-11 without micronutrients $(17.0 \mathrm{~N}-2.2 \mathrm{P}-9.1 \mathrm{~K}$, 12 months), and Osmocote 18-6-12 with micronutrients $(18.0 \mathrm{~N}-2.6 \mathrm{P}-10.0 \mathrm{~K}, 8-9$ months), The Scotts Co., Marysville, Ohio] were surface-applied at rates of 7.2, 10.9, 14.4, and $18.1 \mathrm{~g}$ of $\mathrm{N}$ per container. Plants were irrigated daily at $12 \mathrm{~mm}$ through overhead sprinklers using water from an on-site well (49 $\mathrm{m}$ depth). The numbers of plants were reduced by one third when the containers were spaced $45 \mathrm{~cm}$ on center by the end of Nov. 1999. Each container of the five landscape plant species received the aforementioned Osmocote 18-6-12 controlled release fertilizer at a rate of $7.0 \mathrm{~g}$ of $\mathrm{N}$ in Dec. 1999 and Sept. 2000, respectively. No pesticides were 
used in this production area except for two applications of Banner Maxx (Propiconazole; Novartis, Greensboro, N.C.) to azaleas in Summer 1999 for leaf scorch disease (Septoria azalea). These plants continued to grow in this container production area until the last of the greenhouse plants were harvested.

Rainwater from a greenhouse roof (surface area of $27.3 \mathrm{~m}^{2}$ ) was also collected into the basin. The ratio of outdoor production surface area to the greenhouse roof area was $2: 1$. This was the ratio requested by the St. Johns River Water Management District, Fla., to represent potential sources of collection basin water for the average production nursery-greenhouse operations within its jurisdiction.

Captured water, filtered through a micro screen $(130 \mu \mathrm{m})$ filter, and the on-site well water (the well mentioned above) were delivered to containers of greenhouse-grown foliage and bedding plants through overhead sprinkler and ebb-and-flow systems. For the ebb-and-flow system, grooved $2.4 \mathrm{~m}^{2}$ ebband-flow trays were leveled on greenhouse benches. Both captured water and well water were stored in closed polybutylene 75-L receptacles (Rubbermaid, Winchester, Va.). Initially, $24.0 \mathrm{~N}-3.5 \mathrm{P}-13.3 \mathrm{~K}$ water-soluble fertilizer (Peter's 24-8-16, Grace-Sierra Horticultural Products, Milpitas, Calif.) with micronutrients was added to the receptacles at a rate of $0.5 \mathrm{~g} \cdot \mathrm{L}^{-1}$, resulting in a $\mathrm{N}$ concentration of $120 \mathrm{mg} \cdot \mathrm{L}^{-1}$ and electrical conductivity (EC) of $\approx 1.0 \mathrm{dS} \cdot \mathrm{m}^{-1}$. Each receptacle was equipped with a submersible pump, controlled by an automatic timer. Plants grown on ebb-and-flow trays were fertigated with this water-soluble fertilizer only by pumping stored solution into the trays to a depth of $2.5 \mathrm{~cm}$ for $10 \mathrm{~min}$ one to three times a week, depending on plant growth and season. Solutions were then permitted to drain back into the storage receptacles (Conover and Poole, 1992). Soluble salts in receptacles were monitored weekly. Ammonium and nitrate were examined biweekly using the methods described by Nelson (1983) and West and Ramachandran (1966), respectively. An appropriate amount of fertilizer was added to maintain soluble salt levels at $\approx 1.0 \mathrm{dS} \cdot \mathrm{m}^{-1}$ and $\mathrm{N}$ in a range of 100 to $120 \mathrm{mg} \cdot \mathrm{L}^{-1}$.

Plants watered using overhead irrigation were placed in $929 \mathrm{~cm}^{2}$ water collectors (Landmark Plastics, Akron, Ohio) to channel water falling between the containers into the container bottoms. These overhead-irrigated plants received an $18.0 \mathrm{~N}-2.6 \mathrm{P}-10.0 \mathrm{~K}$ controlled-released fertilizer with micronutrients (Osmocote 18-6-12,8-9 month duration, The Scotts Co., Marysville, Ohio) only by applying $2 \mathrm{~g}$ and $5 \mathrm{~g}$ per $10-\mathrm{cm}$ and $15-\mathrm{cm}$ container, respectively, to the surface of substrate. Controlled released fertilizer was used to comply with the Best Management Practices (BMPs, 1997) to reduce groundwater contamination from nitrate and phosphorus. Water from the collection basin or well was overhead irrigated one to three times a week at $6.7 \mathrm{~mm}$ per application, depending on plant growth and season. To contain irrigation overshoot, curtains were installed around overhead-irrigated bench sections and were closed only during irrigation.
Water volumes applied through ebb-and-flow or overhead, regardless of water source, were separately recorded based on irrigation method by water meters.

Plant materials and container substrate. Uniform foliage plant liners derived from either tissue culture or cuttings were selected and transplanted in $15-\mathrm{cm}$ containers using Vergo Container Mix A (Verlite Co. Tampa, Fla.). Bedding plant seedlings were transplanted in $10-\mathrm{cm}$ containers with the same substrate. The components of the substrate, by volume, were $60 \%$ Canadian peat, $20 \%$ vermiculite, and $20 \%$ perlite. Over a 2 -year period, a total of 18 foliage and 8 bedding plant species/cultivars were evaluated (Table 1), of which the same cultivar of Arrowhead Vine, English Ivy, Philodendron, and Umbrella Tree were evaluated twice. Different species were grown on the same benches or ebb-and-flow trays. Once one crop of a species was harvested, another crop was potted to fill the space.

Plant growth environment and growthmeasurements. All plants were grown in a shaded and evaporated pad cooled greenhouse under a maximum photosynthetically active radiation of $285 \mu \mathrm{mol} \cdot \mathrm{m}^{-2} \cdot \mathrm{s}^{-1}$. Temperatures ranged from 18.3 to $32.2{ }^{\circ} \mathrm{C}$ and relative humidity (RH) from $50 \%$ to $80 \%$.

Plant growth was closely monitored, including daily inspection for plant growth disorders. Initial plant height and widths were recorded. After attaining marketable sizes, plant height and widths were again measured. Growth index (GI) was calculated as GI $=[$ (canopy widest width + width perpendicular $) \div 2] \times$ plant height. Plants were graded visually for overall quality, as described by Stamps and Evans (1999), where: $1=$ poor; 2 = substandard, unsalable; 3 = good, salable; 4 = very good; and $5=$ excellent. Plant shoots were harvested by cutting at the substrate surface, and shoot dry weight was determined after drying in a forced-air oven for $48 \mathrm{~h}$ at $80^{\circ} \mathrm{C}$.

Water quality analysis. Water from the collection basin and well were sampled by staff from St. Johns River Water Management District (SJRWMD), Fla., on 22 Sept. and 7 Dec. 1999, and 30 May, 7 June, and 21 Aug. 2000. Water alkalinity, EC, pH, dissolved oxygen, turbidity, and hardness, as well as $\mathrm{NO}_{3}-\mathrm{N}, \mathrm{NH}_{4}-\mathrm{N}, \mathrm{Kjeldahl} \mathrm{N}, \mathrm{PO}_{4}$, total $\mathrm{P}, \mathrm{Ca}$, $\mathrm{Mg}, \mathrm{Fe}, \mathrm{Cu}, \mathrm{Zn}, \mathrm{Cl}$, and $\mathrm{SO}_{4}$ concentrations were determined based on the U.S. Environmental Protection Agency (EPA) methods (U.S. EPA, 1993). Rainfall during the course of this study was obtained from a Florida Automated Weather Network (FAWN) station situated on site.

The $\mathrm{pH}$ of captured water in the collection basin and in greenhouse pipes, well water in greenhouse pipes, and substrate irrigated using captured water and well water by both irrigation systems was monitored monthly during 2000. Soluble salts and $\mathrm{pH}$ in these substrates were tested by extracting bulk solution from randomly sampled containers using the VPI pour-through method (Yeager et al., 1983).

Experimental design and data analysis. The experimental design was a randomized block design with three replications. Plant quality rating, growth index, and dry weight were analyzed separately by species and trials (for those species utilized twice) as a 2 $\times 2$ factorial consisting of water source and irrigation method with three blocks of three plants each using the Statistical Analysis System (SAS Inst., 1992, Cary, N.C.). When significant $(P<0.05)$ differences occurred within a measured parameter, means were separated using Fisher's Protected Least Significant Differences at the 5\% level.

\section{Results and Discussion}

Water capture. The collection basin reached full capacity in Apr. 1999 after its completion in early Mar. 1999. The basin was uncovered, and algae soon bloomed but were not treated by any physical or chemical means. The volume of water ranged from 24 to $26 \mathrm{~m}^{3}$ year-round, with several occasional overflows due to heavy rain.

Water quality. Means and ranges of measured characteristics of captured and well water are presented in Table 2. Alkalinity, EC, hardness, $\mathrm{Cl}, \mathrm{Ca}, \mathrm{Mg}$, and $\mathrm{SO}_{4}$ of captured water initially were lower than those of well water, then rose to reach or exceed those of well water around May 2000, and finally stabilized or declined slightly to those levels of well water in Aug. 2000. The change of these variables could be explained by the relationship between rainfalls and EC readings during the period of water sampling (Fig.1). Total rainfall during this experimental period was $1,667 \mathrm{~mm}$. Daily average rainfalls decreased from $5.6 \mathrm{~mm}$ during 1 Apr. to 22 Sept. 1999 to $0.2 \mathrm{~mm}$ in early June 2000. Conversely, EC readings of captured water increased from $0.15 \mathrm{dS} \cdot \mathrm{m}^{-1}$ to above $0.4 \mathrm{dS} \cdot \mathrm{m}^{-1}$ during the corresponding sampling period. When rainfall increased in June 2000, EC correspondingly declined. The EC readings of well water slightly varied with time.

The $\mathrm{NH}_{4}^{+}-\mathrm{N}$ concentrations in both captured and well waters were almost negligible, even though captured water's $\mathrm{NH}_{4}^{+}-\mathrm{N}$ was higher than that of well water. Levels of $\mathrm{NO}_{3}-\mathrm{N}$ in well water ranged from 1.2 to $2.1 \mathrm{mg} \cdot \mathrm{L}^{-1}$, but was barely detectable in captured water. Total Kjeldahl $\mathrm{N}$ in captured water increased from 1.7 to $5.1 \mathrm{mg} \cdot \mathrm{L}^{-1}$ over the sampling period with a mean of $3.4 \mathrm{mg} \cdot \mathrm{L}^{-1}$. Captured water also had higher $\mathrm{PO}_{4}$-P and total $\mathrm{P}$ than well water. These data imply that $\mathrm{N}$ and $\mathrm{P}$ were accumulated in the basin, which is largely attributed to irrigation water runoff carrying nutrients from the controlled-release fertilizers. Iron concentrations were initially high in both the captured and well waters, declined in May 1999, and stabilized around $10 \mu \mathrm{g} \cdot \mathrm{L}^{-1}$ during 2000 for both sources. Zinc concentrations of the well water ranged from 16.6 to $162 \mu \mathrm{g} \cdot \mathrm{L}^{-1}$ with a mean of $104.6 \mu \mathrm{g} \cdot \mathrm{L}^{-1}$, which was higher than the mean of captured water. Copper concentrations varied but were generally $<5 \mu \mathrm{g} \cdot \mathrm{L}^{-1}$ in both water sources.

Turbidity of captured water increased from 7.8 to $48.4 \mathrm{ntu}$ (nephelometric turbidity unit) during the sampling period, which 
Table 1. Plants grown with captured (rainwater and irrigation runoff) and well water in a shaded greenhouse.

\begin{tabular}{|c|c|c|c|c|}
\hline Common name & Scientific name & Cultivar & $\begin{array}{l}\text { Production } \\
\text { period (week) }\end{array}$ & $\begin{array}{l}\text { Initiation } \\
\text { date }\end{array}$ \\
\hline \multicolumn{5}{|c|}{ Bedding plants } \\
\hline Snapdragon & Antirrhinum majus $\mathrm{L}$. & Floral Show Mix & 7 & $5 / 04 / 99$ \\
\hline Wax Begonia & Begonia $\times$ semperflorens-cultorum & Ambassador Scarlet & 7 & $5 / 04 / 99$ \\
\hline Vinca & Catharanthus roseus $\mathrm{L}$. & Cooler Peppermint & 8 & 7/26/99 \\
\hline Vinca & Catharanthus roseus $\mathrm{L}$. & Pacifica Lipstick & 9 & $10 / 13 / 99$ \\
\hline Vinca & Catharanthus roseus $\mathrm{L}$. & Pacifica Pink & 9 & $3 / 09 / 00$ \\
\hline New Guinea Impatiens & Impatiens hawkeri Bull. & Accent Red & 9 & $5 / 04 / 99$ \\
\hline New Guinea Impatiens & Impatiens hawkeri Bull. & Super Elfin Pink & 7 & $7 / 26 / 99$ \\
\hline New Guinea Impatiens & Impatiens hawkeri Bull. & Super Elfin White & 8 & $3 / 09 / 00$ \\
\hline \multicolumn{5}{|c|}{ Foliage plants } \\
\hline Chinese evergreen & Aglaonema & Maria & 32 & $5 / 12 / 99$ \\
\hline Flamingo Lily & Anthurium $\mathrm{x}$ & Cotton Candy & 24 & $8 / 10 / 99$ \\
\hline Baby Doll Ti & Cordyline terminalis $\mathrm{L}$. & Baby Doll & 11 & $6 / 07 / 00$ \\
\hline Grape Ivy & Cissus rhombifolia & Grape Ivy & 14 & $10 / 05 / 00$ \\
\hline Areca Palm & Chrysalidocarpus lutescens $\mathrm{H}$. Wendl. & --- & 30 & $3 / 09 / 00$ \\
\hline Dumb Cane & Dieffenbachia maculata (Lodd.) G. Don & Perfection compacta & 15 & $5 / 04 / 99$ \\
\hline Dumb Cane & Dieffenbachia $\mathbf{x}$ & Snowflake & 20 & $8 / 31 / 00$ \\
\hline Dragon Tree & Dracaena marginata Lam. & Bicolor & 21 & $5 / 04 / 99$ \\
\hline Dragon Tree & Dracaena marginata Lam. & Tricolor & 21 & $8 / 31 / 00$ \\
\hline Pothos & Epipremnum aureum (Linden \& Andre) Bunt. & Golden Pothos & 20 & $7 / 30 / 99$ \\
\hline Weeping Fig & Ficus benjamina $\mathrm{L}$. & Common & 45 & $10 / 13 / 99$ \\
\hline English Ivyz & Hedera helix $\mathrm{L}$. & Pia & 15 & $5 / 04 / 99$ \\
\hline Boston Sword Fern & Nephrolepis exaltata (L.) Schott. & Bostoniensis compacta & 14 & $5 / 04 / 99$ \\
\hline Boston Sword Fern & Nephrolepis exaltata (L.) Schott. & Blue Bell & 15 & $9 / 11 / 00$ \\
\hline Philodendron $^{\mathrm{z}}$ & Philodendron $\mathrm{x}$ & Black Cardinal & 38 & $5 / 04 / 99$ \\
\hline Umbrella Tree $^{z}$ & Schefflera actinophylla F. Muell. & Amate & 25 & 4/09/99 \\
\hline Peace Lily & Spathiphyllum $\mathrm{x}$ & Petite & 17 & $5 / 04 / 99$ \\
\hline Arrow-Head Vine ${ }^{z}$ & Syngonium podophyllum Schott. & Pink Allusion & 14 & $7 / 26 / 99$ \\
\hline
\end{tabular}

${ }^{2}$ The same cultivars were evaluated twice during the 2 years of experimentation. The second evaluation began: English Ivy

11 Jan. 2000; Philodendron 25 Sept. 2000; Umbrella Tree 11 Oct. 1999; Arrow-Head Vine 9 Oct. 2000.

was ascribed to growth of algae. With the flow of nutrients, particularly $\mathrm{N}$ and $\mathrm{P}$, to the collection basin, and appropriate temperature range, algae grew and flourished. This probably explains the low concentrations $\mathrm{NH}_{4}^{+}-\mathrm{N}$ and $\mathrm{NO}_{3}-\mathrm{N}$ and high levels of Kjeldahl $\mathrm{N}$ in the captured water. Photosynthetic activity of algae led to an increased $\mathrm{pH}$ in captured water (Badger and Price, 1994; Stumm and Morgan, 1996). The $\mathrm{pH}$ of well water ranged from 7.3 to 8.0 , whereas that of the captured water ranged from 9.3 to 10.3 during the sampling period. Concomitantly, dissolved $\mathrm{O}_{2}$ increased from
$6.2 \mathrm{mg} \cdot \mathrm{L}^{-1}$ in Sept. 1999 to $13.2 \mathrm{mg} \cdot \mathrm{L}^{-1}$ in May 2000 and stabilized at $\approx 10 \mathrm{mg} \cdot \mathrm{L}^{-1}$ from June to Aug. 2000 in captured water, which was markedly higher than that of well water.

There is a general agreement on the level of alkalinity $\left(\leq 100 \mathrm{mg} \cdot \mathrm{L}^{-1}\right), \mathrm{EC}\left(<0.5 \mathrm{dS} \cdot \mathrm{m}^{-1}\right)$, $\mathrm{pH}(5$ to 7$), \mathrm{NH}_{4}^{+}-\mathrm{N}, \mathrm{NO}_{3}-\mathrm{N}, \mathrm{P}$, and $\mathrm{SO}_{4}(<5$ $\left.\mathrm{mg} \cdot \mathrm{L}^{-1}\right), \mathrm{Cl}\left(<140 \mathrm{mg} \cdot \mathrm{L}^{-1}\right), \mathrm{Ca}\left(<120 \mathrm{mg} \cdot \mathrm{L}^{-1}\right)$, and $\mathrm{Mg}\left(<24 \mathrm{mg} \cdot \mathrm{L}^{-1}\right)$ of water that is considered to be desirable for irrigation of greenhouse crops (Argo et al., 1997; Peterson and Kramer, 1989; Tayama, 1991). Based on data presented in Table 2, characteristics of both captured

Table 2. Characteristics of captured (rainwater and irrigation runoff) and well water used for the production of greenhouse foliage and bedding plants.

\begin{tabular}{lcccccc}
\hline & & \multicolumn{2}{c}{ Captured water } & & \multicolumn{2}{c}{ Well water } \\
\cline { 3 - 4 } \cline { 6 - 7 } Characteristic & Unit & Mean & Range $^{2}$ & & Mean & Range \\
\hline Alkalinity & $\mathrm{mg} \cdot \mathrm{L}^{-1}$ & 95.0 & $49.7-123.2$ & & 111.8 & $106.5-119.2$ \\
$\mathrm{EC}$ & $\mathrm{dS} \cdot \mathrm{m}^{-1}$ & 0.34 & $0.15-0.43$ & & 0.37 & $0.36-0.44$ \\
$\mathrm{pH}$ & --- & 9.7 & $9.3-10.3$ & & 7.6 & $7.3-8.0$ \\
Turbidity & $\mathrm{ntu}^{y}$ & 26.4 & $7.8-48.4$ & & 0.5 & $0.2-1.3$ \\
Hardness & $\mathrm{mg} \cdot \mathrm{L}^{-1}$ & 126.6 & $58.0-167.0$ & & 140.8 & $135.0-146.0$ \\
Dissolved $\mathrm{O}_{2}$ & $---^{-}$ & 10.2 & $6.2-13.2$ & & 3.8 & $3.1-5.7$ \\
$\mathrm{NH}_{4}-\mathrm{N}$ & --- & 0.06 & $0.015-0.127$ & & 0.004 & $0.003-0.009$ \\
$\mathrm{NO}_{3}-\mathrm{N}$ & --- & 0.04 & $0.002-0.08$ & & 1.56 & $1.15-2.09$ \\
$\mathrm{Kjeldahl} \mathrm{N}$ & --- & 3.4 & $1.7-5.1$ & & 1.6 & $1.2-2.4$ \\
$\mathrm{Cl}$ & --- & 12.8 & $5.67-19.05$ & & 13.4 & $13.56-14.16$ \\
$\mathrm{P}$ & --- & 0.45 & $0.18-0.81$ & & 0.11 & $0.10-0.13$ \\
Total P & --- & 0.87 & $0.48-1.42$ & & 0.12 & $0.11-0.13$ \\
$\mathrm{Ca}$ & --- & 28.5 & $12.3-42.2$ & & 33.7 & $29.3-35.8$ \\
$\mathrm{Mg}$ & --- & 13.4 & $6.7-21.4$ & & 13.7 & $12.9-15.0$ \\
$\mathrm{SO}{ }_{4}$ & --- & 29.1 & $10.6-45.8$ & & 23.4 & $19.6-28.7$ \\
$\mathrm{Fe}$ & $\mu \mathrm{g} \cdot \mathrm{L}^{-1}$ & 35.2 & $9.6-106$ & & 49.4 & $7.9-126$ \\
$\mathrm{Cu}$ & --- & 2.8 & $1.4-4.2$ & & 6.6 & $0.07-23.4$ \\
$\mathrm{Zn}$ & --- & 18.9 & $6.1-35.0$ & & 104.6 & $16.6-162.0$ \\
\hline
\end{tabular}

${ }^{2}$ The range indicated the maximum and minimum values of measured parameters across the sampling period from 22 Sept. 1999 to 21 Aug. 2000.

${ }^{y}$ ntu $=$ nephelometric turbidity unit.

${ }^{\times}$The same unit as the previous characteristics.

and well water were well within the desired levels except that the $\mathrm{pH}$ and turbidity of the captured water were in excess.

Monthly monitoring of $\mathrm{pH}$ of captured water in the collection basin, in greenhouse pipes, and in the substrate suggested $\mathrm{pH}$ values fluctuated over time (Fig. 2). The mean value was 9.7 in the collection basin, 8.8 in greenhouse pipes, and 6.6 in the substrate irrigated with captured water; the mean was 7.4 for well water in greenhouse pipes and 6.3 in well-water-irrigated substrate, regardless of irrigation system. In addition to the relatively low alkalinity of both captured and well water, indicating weak buffering capacity, the $\mathrm{pH}$ differences between collection basin and greenhouse pipes could be explained by the minimizing of algae in the pipes due to the filtration. The drop of the $\mathrm{pH}$ in substrate was likely due to the strong buffering capacity of the substrate, consisting mainly of sphagnum peat and vermiculite (Handreck and Black, 1994) and also to the fertilizer effects since the water-soluble fertilizer and Osmocote used have $7.2 \%$ and $9.7 \%$ ammoniac nitrogen, respectively.

Plant production. Liners or seedlings of the same species potted at the same time attained marketable sizes concurrently regardless of water source or irrigation system (data not shown). No disease incidences were observed throughout the 2-year production period, although pathogenic Erwinia chrysanthemi and E. c. subsp. carotovora were identified in captured water using a PCR fingerprinting method (Norman et al., 2001). No growth disorders appeared except in Philodendron 'Black Cardinal' which manifested small yellowish 


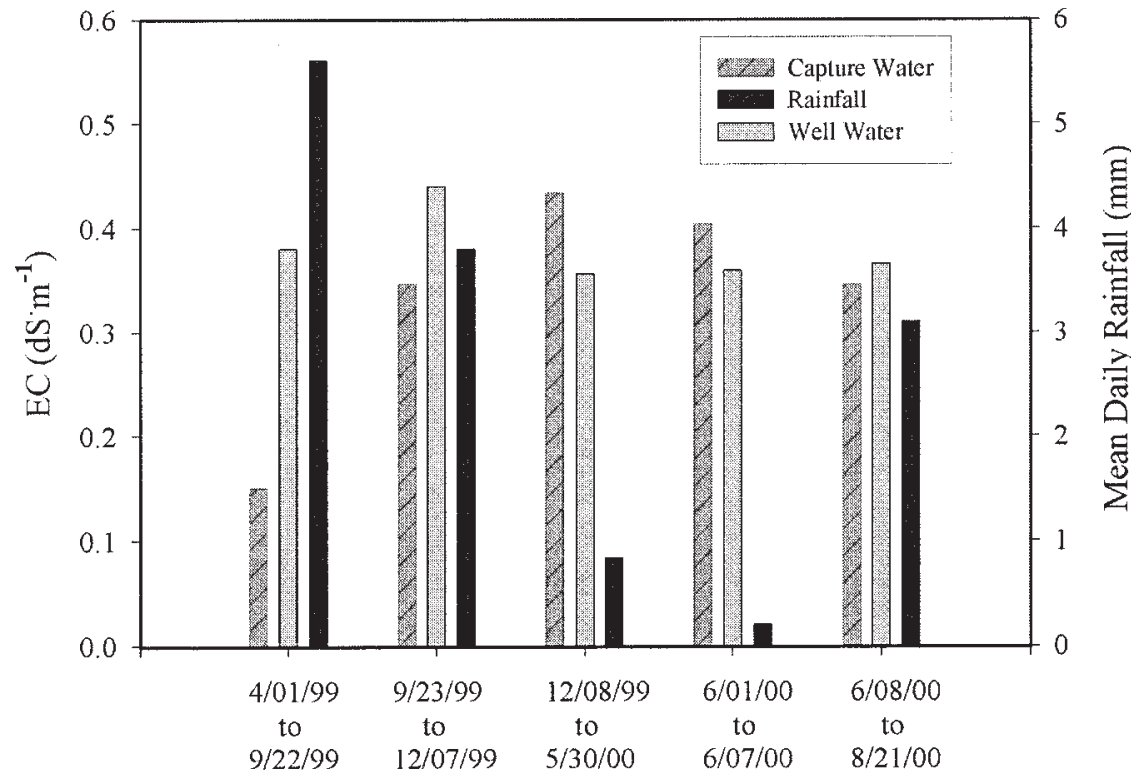

Sampling Period

Fig. 1. The relationship between rainfall and electrical conductivity (EC) readings of captured rainwater and irrigation runoff in the collection basin and of well water. Daily average rainfall was the total rainfall during the periods indicated on the horizontal axis divided by the number of days. The EC was read from water sampled on the last day of each period indicated.

spots on the leaves. The cause of this problem was unknown but independent of water source or irrigation method since all plants in two separate trials showed the same symptom. In addition, all marketable plants were graded high, ranging from 4 to 5 . There was no water source or irrigation system related difference in quality ratings (data not shown).

Statistical analyses of growth indices and shoot dry weight indicated that water source

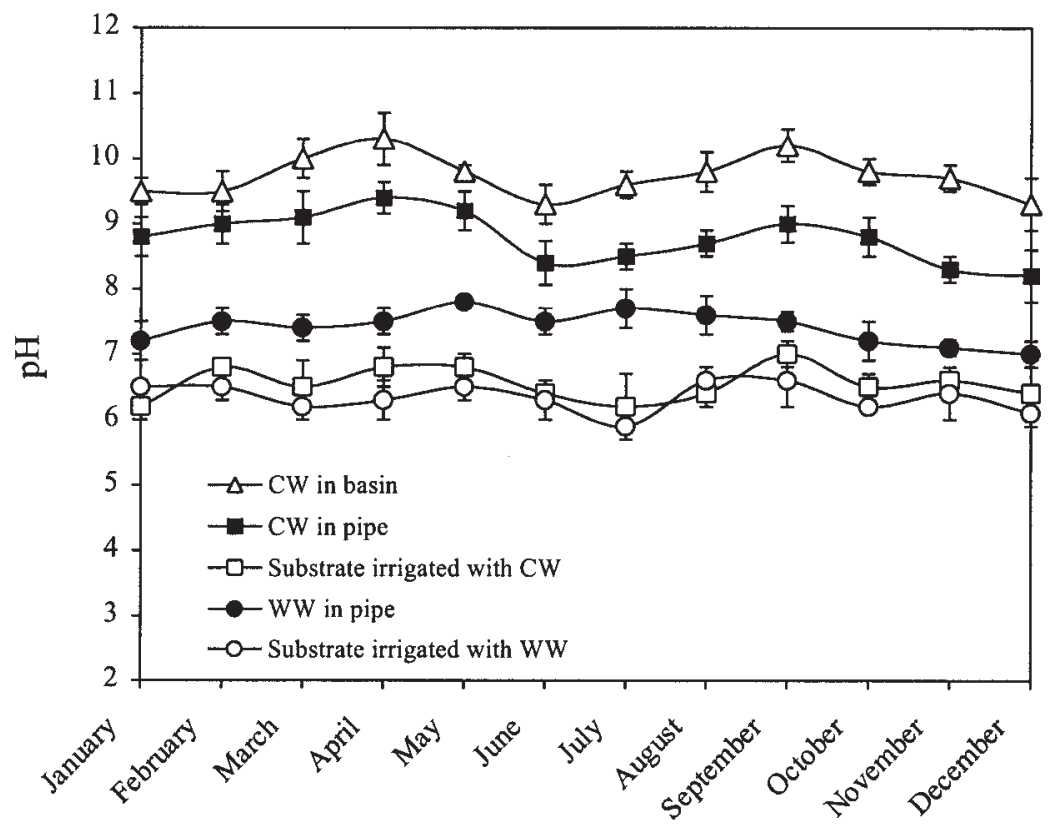

Month

Fig. 2. Monthly $\mathrm{pH}( \pm \mathrm{SE})$ in captured rainwater and irrigation runoff $(\mathrm{CW})$ in the collection basin and in the greenhouse pipe, and in well water (WW) in greenhouse pipe as well as in random selected substrate irrigated using the captured water and well water through ebb-and-flow irrigation in 2000. Bars represent SE of three replications.
Epipremnum aureum 'Golden Pothos', Hedera helix 'Pia' (two trials), Nephrolepis exaltata 'Bostoniensis compacta' and 'Blue Bell', Philodendron 'Black Cardinal' (two trials), and Syngonium podophyllum 'Pink Allusion' (two trials) (data not shown). For other species and trials, the interaction of water sources and irrigation systems were significant $(P<0.05)$. Thus, analyses were focused on the interactions (Snedecor and Cochran, 1980).

Plant growth indices that were significantly $(P<0.05)$ affected by the interaction between water source and irrigation system are listed in Table 3. In general, plants irrigated using the ebb-and-flow system exhibited larger growth indices than those irrigated overhead except for Cordyline terminalis 'Baby Doll' and Dieffenbachia maculata 'Perfection Compacta', which had larger growth indices with overhead irrigation. Among this group of plants, captured water resulted in larger Impatiens hawkeri 'Super Elfin White' than well water when irrigated through the ebband-flow system.

The interaction between water source and irrigation system also significantly $(P$ $<0.05$ ) affected dry weight accumulation of some species (Table 4). Ebb-and-flow irrigation produced more dry weight than overhead irrigation except for Cordyline terminalis 'Baby Doll' and Dieffenbachia maculata 'Perfection Compacta', whose dry weights were greater when irrigated overhead. Moreover, dry weight of Cordyline terminalis 'Baby Doll' irrigated overhead with captured water was greater than that irrigated with well water. Captured water also produced more dry weights of Impatiens hawkeri 'Super Elfin White' and 'Accent Red' as well as Schefflera actinophylla 'Amate' (first trial) when irrigated using the ebb-and-flow system.

Irrigation method-related differences in growth indices or dry weight (Table 3 and 4) could be attributed to interactions of irrigation methods with fertilizer formulations and plant genetic makeup. Most plants listed in either Table 3 or 4 had larger growth indices or greater dry weights when irrigated using ebb-and-flow than when irrigated through overhead. This could result from more consistent concentrations of nutrients and water supplied through ebb-and-flow, as opposed to controlled-release fertilizer and overhead irrigation. The amount and duration of nutrient release from controlled-release fertilizer may vary depending on temperature. Released nutrients may also have been partially leached by overhead irrigation even though, overall, similar amounts of $\mathrm{N}$ were applied, regardless of fertilizer types, irrigation method, and plant species/cultivars. Argo and Biernbaum (1995) reported that $\mathrm{N}$ rates in subirrigation could be reduced by $50 \%$ compared to traditional overhead irrigation in poinsettia production. However, Cordyline terminalis 'Baby Doll' and Dieffenbachia maculata 'Perfection Compacta' had larger growth indices and greater dry weight when irrigated overhead. Irrigation system and fertilizer interactions influencing plant performance have also been demon- 
Table 3. Mean growth indices $\left(\mathrm{cm}^{2}\right)$ of plants irrigated through ebb-and-flow or overhead irrigation using captured (rainwater and irrigation runoff) and well water sources.

\begin{tabular}{lccccc}
\hline & \multicolumn{2}{c}{ Overhead } & & \multicolumn{2}{c}{ Ebb-and-flow } \\
\cline { 2 - 3 } \cline { 6 - 7 } Plant & Captured & Well & & Captured & Well \\
\hline I. hawkeri Super Elfin Pink & $454 \mathrm{~b}^{2}$ & $470 \mathrm{~b}$ & & $689 \mathrm{a}$ & $517 \mathrm{ab}$ \\
I. hawkeri Super Elfin White & $858 \mathrm{~b}$ & $677 \mathrm{~b}$ & & $1232 \mathrm{a}$ & $852 \mathrm{~b}$ \\
I. hawkeri Accent Red & $450 \mathrm{~b}$ & $474 \mathrm{~b}$ & & $1118 \mathrm{a}$ & $1036 \mathrm{a}$ \\
C. roseus Pacific Lipstick & $389 \mathrm{~b}$ & $447 \mathrm{~b}$ & & $575 \mathrm{a}$ & $493 \mathrm{ab}$ \\
Anthurium Cotton Candy & $1254 \mathrm{~b}$ & $1356 \mathrm{~b}$ & & $1471 \mathrm{ab}$ & $1588 \mathrm{a}$ \\
Aglaonema Maria & $1605 \mathrm{~b}$ & $1465 \mathrm{~b}$ & & $2354 \mathrm{a}$ & $2135 \mathrm{a}$ \\
C. terminalis Baby Doll & $1956 \mathrm{a}$ & $1830 \mathrm{ab}$ & & $1603 \mathrm{bc}$ & $1588 \mathrm{c}$ \\
D. maculata Perfection compacta & $1422 \mathrm{a}$ & $1278 \mathrm{a}$ & & $1039 \mathrm{~b}$ & $1044 \mathrm{~b}$ \\
F. benjamina Common & $7606 \mathrm{~b}$ & $8579 \mathrm{~b}$ & & $13669 \mathrm{a}$ & $12888 \mathrm{a}$ \\
S. actinophylla Amate $\left(2^{\text {nd }}\right.$ trial $)$ & $3083 \mathrm{bc}$ & $2681 \mathrm{c}$ & & $4102 \mathrm{a}$ & $3964 \mathrm{ab}$ \\
\hline
\end{tabular}

${ }^{2}$ Means within rows followed by different letters are significant different $(P<0.05)$ based on Fisher's protected least significant difference.

Table 4. Mean shoot dry weight $(\mathrm{g})$ of plants irrigated by ebb-and-flow or overhead using captured (rainwater and irrigation runoff) and well water sources.

\begin{tabular}{|c|c|c|c|c|}
\hline \multirow[b]{2}{*}{ Plant } & \multicolumn{2}{|c|}{ Overhead } & \multicolumn{2}{|c|}{ Ebb-and-flow } \\
\hline & Captured & Well & Captured & Well \\
\hline I. hawkeri Super Elfin Pink & $2.9 \mathrm{~b}^{2}$ & $2.9 \mathrm{~b}$ & $4.3 \mathrm{a}$ & $4.8 \mathrm{a}$ \\
\hline I. hawkeri Super Elfin White & $1.7 \mathrm{ab}$ & $1.4 \mathrm{~b}$ & $2.4 \mathrm{a}$ & $1.2 \mathrm{~b}$ \\
\hline I. hawkeri Accent Red & $1.1 \mathrm{c}$ & $1.3 \mathrm{c}$ & $2.8 \mathrm{a}$ & $2.1 \mathrm{~b}$ \\
\hline C. terminalis Baby Doll & $18.5 \mathrm{a}$ & $15.7 \mathrm{~b}$ & $13.2 \mathrm{c}$ & $12.6 \mathrm{c}$ \\
\hline D. maculata Perfection compacta & $21.5 \mathrm{a}$ & $17.9 \mathrm{ab}$ & $13.9 \mathrm{~b}$ & $14.6 \mathrm{~b}$ \\
\hline F. benjamina Common & $86.9 \mathrm{~b}$ & $95.0 \mathrm{~b}$ & $151.6 \mathrm{a}$ & $128.8 \mathrm{a}$ \\
\hline S. actinophylla Amate & $35.4 \mathrm{ab}$ & $32.5 \mathrm{ab}$ & $37.9 \mathrm{a}$ & $28.6 \mathrm{~b}$ \\
\hline S. actinophylla Amate ( $2^{\text {nd }}$ trial) & $19.3 \mathrm{~b}$ & $17.4 \mathrm{~b}$ & $24.8 \mathrm{a}$ & $25.5 \mathrm{a}$ \\
\hline Spathiphyllum Petite & $74.8 \mathrm{bc}$ & $66.8 \mathrm{c}$ & $91.4 \mathrm{a}$ & $85.2 \mathrm{ab}$ \\
\hline
\end{tabular}

${ }^{2}$ Means within rows followed by different letters are significant different $(P<0.05)$ based on Fisher's protected least significant difference.

strated in geranium (Knight et al., 1993) and petunia (Klock-Moore and Broschat, 2001). Plant genetic makeup appears to have affected the interaction of irrigation system with fertilizer type. For example, no differences in growth index and dry weight were observed in Dieffenbachia x 'Snow Flake', however, Dieffenbachia maculata 'Perfection Compacta' grew larger with overhead compared to ebb-and-flow irrigation.

The reason for captured water resultant larger growth indices or greater dry weight within an irrigation system in some plant species (Table 3 and 4 ) is unclear. It does not appear to be explained by the seasonal variation of nutrient concentrations in captured water. For example, Schefflera actinophylla 'Amate' in the first trial, occurring from Apr. to Oct. 1999 , produced significantly $(P<0.05)$ more dry weight when irrigated with captured water than well water (Table 4). During this period, EC readings of captured water were lower than that of well water $\left(0.15 \mathrm{vs} .0 .38 \mathrm{dS} \cdot \mathrm{m}^{-1}\right)$. Yet, in a second trial, occurring from Oct. 1999 to Apr. 2000, there were no water source-related dry weight differences. During the second trial period, EC readings of both captured and well water were about the same (Fig. 1).

Assessing captured water as an alternative irrigation source. Water, captured from a $54.6 \mathrm{~m}^{2}$ landscape plant production area blended with rainwater collected from a 27.3 $\mathrm{m}^{2}$ greenhouse roof area, not only satisfied the need of plants in a $38-\mathrm{m}^{2}$ greenhouse yearround, but also maintained the collection basin near full capacity $\left(26.5 \mathrm{~m}^{3}\right)$. Average volumes of irrigation applied by the ebb-and-flow and overhead systems during this experiment were 11 and $36 \mathrm{~m}^{3}$ per $100 \mathrm{~m}^{2}$ of production area per crop, respectively. If two crops were produced annually in this greenhouse, the remaining captured water should be sufficient to meet this irrigation requirement of an additional mix of species in a $120-\mathrm{m}^{2}$ production area annually using ebb-and-flow irrigation and in a $37-\mathrm{m}^{2}$ production area with the overhead irrigation system described.

All measured water-quality parameters were well within desired levels for greenhouse crop production except $\mathrm{pH}$ and turbidity that were high due to growth of algae in the captured water. Algae were also noticed in ebb-and-flow trays irrigated with both water sources but not observed in the receptacles and did not cause clogging of pipelines or growth on the container substrate. The high $\mathrm{pH}$ in the collection basin, however, did not affect the $\mathrm{pH}$ of substrate due to the water's low alkalinity and the substrate's high buffer capacity. Neither disease incidences nor growth disorders occurred with either water sources, except for Philodendron mentioned above. As a result, all evaluated plants irrigated with captured water, regardless of irrigation method, exhibited slightly better or at least equal growth index, and dry weight accumulation compared to those irrigated with well water.

Whether or not $\mathrm{pH}$ could become a problem for plant growth, whether algae could eventually clog the pipelines, or plants could be infected by potential pathogens from the capture water, if this experiment were continued, are unknown. However, these problems could be easily resolved by current technologies in water treatments such as ozonization, ultraviolet irradiation, or sulfur dioxide treatments (Marhaba, 2000; Sakamoto, 2000). Capturing rainwater and irrigation water runoff and using the captured water for production of greenhouse crops should be a viable option in regions where fresh water shortage occurs.

\section{Literature Cited}

Argo, W.R. and J.A. Biernbaum. 1995. The effect of irrigation method, water-soluble fertilization, preplant nutrient charge, and surface evaporation of early vegetative and root growth of poinsettia. J. Amer. Soc. Hort. Sci. 120:163-169.

Argo, W.R., J.A. Biernbaum, and D.D. Warncke. 1997. Geographical characterization of greenhouse irrigation water. HortTechnology 7: 49-55.

Badger, M.R. and G.D. Price. 1994. The role of carbonic anhydrase in photosynthesis. Annu. Rev. Plant Physiol. Plant Mol. Biol. 45:369-392.

Berry W.L., A. Wallace, and O.R. Lunt. 1980. Utilization of municipal wastewater for the culture of horticulture crops. HortScience 15: 169-171.

Beeson, R.C., Jr., and G.W. Knox, 1991. Analysis of efficiency of overhead irrigation in container production. HortScience 26:848-850.

BMPs, 1997. Best management practices: Guide for producing Container-grown plants. Southern Nursery Assn. Marietta, Ga.

Burney, L.C., T. Swihart, and J.G. Llewellyn. 1998. Water supply planning in Florida. Fla. Water Res. J. (Oct.) 27-28.

Camper, N.D., T. Whitwell, R. Keese, and M.B. Riley. 1994. Herbicide levels in nursery containment pond water and sediments. J. Environ. Hort. 12:8-12.

Conover, C.A. and R.T. Poole. 1992. Fertilizer levels and medium affect foliage plant growth in an ebb-and-flow irrigation system. J. Environ. Hort. 10:81-86.

Fitzpatrick, G., H. Donselman, and N.S. Carter. 1986. Interactive effects of sewage effluent irrigation and supplemental fertilization on container-grown trees. HortScience 21:92-93.

Handreck, K.A. and N.D. Black. 1994. Growing Media for Ornamental Plants and Turf. Univ. of New South Wales Press. Randwick, NSW Australia.

Harrison, D.S. 1976. Irrigation water applied to three commercial ornamental container nurseries. Proc. Fla. State Hort. Soc. 90:306-308.

Klock-Moore, K.A. and T.K. Broschat. 2001. Irrigation systems and fertilizer affect petunia growth. HortTechnology 11:416-418.

Knight, P.R., D.J. Eakes, and C.H. Gilliam. 1993. Method of irrigation and fertilizer application influence growth and nitrogen recovery for 'Scarlet Elite' geranium. HortScience 28:477. (Abstr.).

Marhaba, T.F. 2000. Crystal clear. Environ. Protection 11(8):38-47.

Neal, C.A. and R.W. Henley. 1992. Water use and runoff comparison of greenhouse irrigation systems. Proc. Fla. State Hort. Soc. 105: 191-194.

Nelson, D.W. Determination of ammonium in $\mathrm{KCl}$ extracts by the salicylate method. Comm. Soil Sci. Plant Anal. 14:1051-1062.

Norman, D.J., J.M.F. Yuen, L. Reich, and R. Resendiz. 2001. Use of rep-PCR fingerprinting to compare populations of Erwinia from ornamentals with those found in irrigation and stormwater runoff. Phytopathology 91:S66 (Abstr.).

Peterson, J.C. and L.L. Kramer. 1989. Water quality. p. 26-27. In: Tips on Growing Potted Chrysan- 
themums. Ohio Coop. Ext. Serv. Bul. FP-767.

Quist, T.M.,C.F. Williams, and M.L. Robinson. 1999.

Effects of varying water quality on grown and appearance of landscape plants. J. Environ. Hort. 17:88-91.

Sakamoto, G. 2000. Finite and nonrenewable: UV disinfection of reclaimed waste water. Environ. Protection 11(10):20-25.

Skimina, C. 1986. Recycling irrigation runoff on container ornamentals. HortScience 21:31-34.

Snedecor, G.W. and W.G. Cochran, 1980. Statistical methods. $7^{\text {th }}$ Edition. The Iowa State Univ. Press, Ames.

Stamps, R.H. and M.R. Evans. 1999. Growth of Dracaena marginata and Spathiphyllum 'Petite' in sphagnum peat- and coconut coir dust-based growing media. J. Environ. Hort. 17:49-52.

Stumm, W. and J.J. Morgan. 1996. Aquatic chemistry: Chemical equilibria and rates in natural water. $3^{\text {rd }}$ ed. Wiley, New York.

Tayama, H. 1991. Test irrigation water to ensure acceptable $\mathrm{pH}$, alkalinity levels. Greenhouse Manager (Oct.) 119.

West, P.W. and T.P. Ramachandran. 1966. Spectrophotometric determination of nitrate using chromotropic acid. Anal. Chim. Acta 35: 317-324.

Wu, L., J. Chen, H. Lin, P. van Mantgem, M.A. Harivandi, and J.A. Harding. 1995. Effects of regenerated wastewater irrigation on growth and ion uptake of landscape plants. J. Environ. Hort. 13:92-96.

Yeager, T.H., G.W. Knox, G.W. Simone, H.M. Gramling, and R. D. Newton. 1989. Efficacy of chlorinated irrigation water for controlling root rot organisms. Intl. Plant. Prop. Soc. Comb. Proc. 39: 399-404.

Yeager, T.H., R.D. Wright, and S.J. Donohue. 1983. Comparison of pour-trough and saturated pine bark extract N, P, K, and $\mathrm{pH}$ levels. J. Amer. Soc. Hort. Sci. 108:112-114.

United States Environmental Protection Agency. 1993. Methods for chemical analysis of water and wasters. EPA-600/4-79-020, Environ. Monitoring and Support Lab., Cincinnati, Ohio. 